\title{
Farmer's Adaptive Strategies To Climate Change in Akinyele Local Government Area, Oyo State, Nigeria
}

\author{
${ }^{1}$ Ismaila Kolade Bamigbade ${ }^{*}{ }^{2}$ Adamu Ahmed, ${ }^{3}$ Muhammed Ballama, \\ ${ }^{4}$ Macdonald N. Onuoha \\ ${ }^{1}$ Department of Internal Medicine \\ Federal University Dutse \\ ${ }^{2}$ Department of Geography \\ Bayero University \\ Kano \\ ${ }^{3}$ Department of Geography \\ Jigawa State College of Education \\ Gumel. \\ ${ }^{4}$ Department of Human Medicine \\ College of Medical Sciences \\ University of Maiduguri
}

Email: Ismailbamigbade@gmail.com

\begin{abstract}
Agriculture and climate change are inextricably linked to crop yield, biodiversity, water use, as well as soil health. The research sets the objectives of describing the socioeconomic characteristics of farmers in Akinyele L.G.A of Oyo state, identifying various adaptive measures and the determinants of appropriate climate-change adaptation measures used by farmers in the agricultural communities of the study area. A sample of farmers who have registered with the Federal Ministry of Agricultural, Growth Enhancement Support Scheme (GES) Akinyele chapter were recruited in the research. Questionnaire was used to gather data on the age, gender, education and farming experiences of the farmers. Data was also collected on these adaptive capacity measures: Membership of social organizations, mixed farming, change from crop production to animal rearing, seeking early warning information on climate change among others. Percentages, frequencies were used to analyze the data. The variables were also subjected to regression analysis.70\% of the farmers in the study area are male and about the same percentage of them fall within the age range of 31-60 years. Only 33\% of the farmers have post- primary education. The result of the regression analysis reveal that planting of improved varieties $(0.841,0.001)$ intensive fertilizer/manure application $(0.005,0.421)$ have positive and significant relationship in determining farmer's adaptation strategies while contour ridging $(1.950,0.970)$ has positive but not significant relationship in determining farmer's adaptation strategies .Change from crop production to animal rearing $(-1.766,0.567)$ has negative and insignificant relationship in determining farmer's adaptation strategies
\end{abstract}

*Author for Correspondence

I. K. Bamigbade, A. Ahmed, M. Ballama, M. N. Onuoha, DUJOPAS 7 (3a): 58-66 2021 
Keywords: Adaptation, Growth Enhancement Support Scheme, Strategies, Climate change, Communities

\section{INTRODUCTION}

Agriculture is an important source of food and fiber, employment and foreign exchange for most developing countries. Agriculture contributes over $40 \%$ of Nigeria's GDP, employs about $70 \%$ of the population, and produces about $80 \%$ of the food needs according to (Aye, 2013). Although, agriculture still accounts for about $88 \%$ of non-oil export earnings, its contribution has seriously declined over the decade falling from about $75 \%$ of total export earnings in the 1960s to less than 3\% currently (Oji-Okoro, 2011). Increasing productivity in agriculture depends heavily on a number of factors including weather and climate conditions. Agriculture and climate change are inextricably linked as crop yield, biodiversity, and water use, as well as soil health are directly affected by a changing climate. Climate change arises due to a number of factors but basically due to human activities, such as the emission of greenhouse gases and changing land uses. It is already affecting the Earth's temperature, precipitation, and hydrological cycles (Intergovermntal Panel on Climate Change, 2007).

Many African countries, Nigeria in particular, which have their economy largely based on weather sensitive agricultural production system are particularly vulnerable to the effects of climate change (Action Aid, 2008).

Oyo state which provides the bulk of arable food crops consumed locally and in other parts of Nigeria have been faced with the problems of crop failure, or low yield arising from variation in climate particularly the delayed onset of rains and the increasing length and frequency of dry spells during the growing season (Adebayo, 2010).

Adaptation is one of the policy options for reducing the negative impact of climate change (Adger et al., 2003; Kurkulasuriya \& Mendelsohn 2008). Studies show that without adaptation, climate change is generally detrimental to the agriculture sector; but with adaptation, vulnerability can largely be reduced (Smit \& Skinner 2002).

Common adaptation methods in agriculture include use of new crop varieties and livestock species, irrigation, crop diversification, adoption of mixed crops and livestock farming systems, and changing planting dates (Bradshaw et al., 2004; Nhemachena \& Hassan 2007).

Studies have been undertaken to analyze the impact of climate change and factors affecting the choice of adaptation methods in crop, livestock and mixed crop livestock production systems in Africa at regional level (Maddision,2006;Kurkulasuriya \& Mendelsohn 2008;Seo \& Mendelsohn,2008; Nhemachena \& Hassan,2007;Hassan \& Nhemachena,2008). Findings showed that these studies have little importance in identifying country specific impacts and adaptation methods given the heterogeneity of countries included. Therefore, there is limited information on types of adaptation strategies used by farmers in Nigeria. Furthermore, the determinants of appropriate climate-change adaptation strategies used by farmers in Nigeria and Oyo state in particular have not been fully investigated. Other past studies on determinants of climate change adaptation used by farmers in Nigeria focused on cash crops and fisheries production with limited emphasis on food crop production (Oyekale et al., 2009; Oyekale \& Oladele, 2012; Obatolu et al.,2003; Arimi, 2014). It is therefore based on this concern that this research seeks to identify the various adaptive measures the farmers adopted in tackling the problems of climate change in Akinyele Local Goverment of Oyo state and their determinants.

\section{Study Area}


Akinyele is a local government in Oyo State, Nigeria. The local government lies between latitude $7026^{\prime} 23^{\prime \prime} \mathrm{N}$ to $7040^{\prime} 30^{\prime \prime} \mathrm{N}$ and between longitude 3 o $47^{\prime} 4^{\prime \prime} \mathrm{E}$ to 4 o $05^{\prime} 00^{\prime \prime} \mathrm{E}$ (Figure 1).Akinyele local government shares boundaries with Afijio Local Government to the north, Lagelu local government area to the east, Ido local government area to the west and Ibadan North local government area to the south. It occupies a land area of 404,892 square kilometers According to the 2006 census as released by the National Population Commission, the population of Akinyele local government was 211,359 (Tokede et al., 2020).

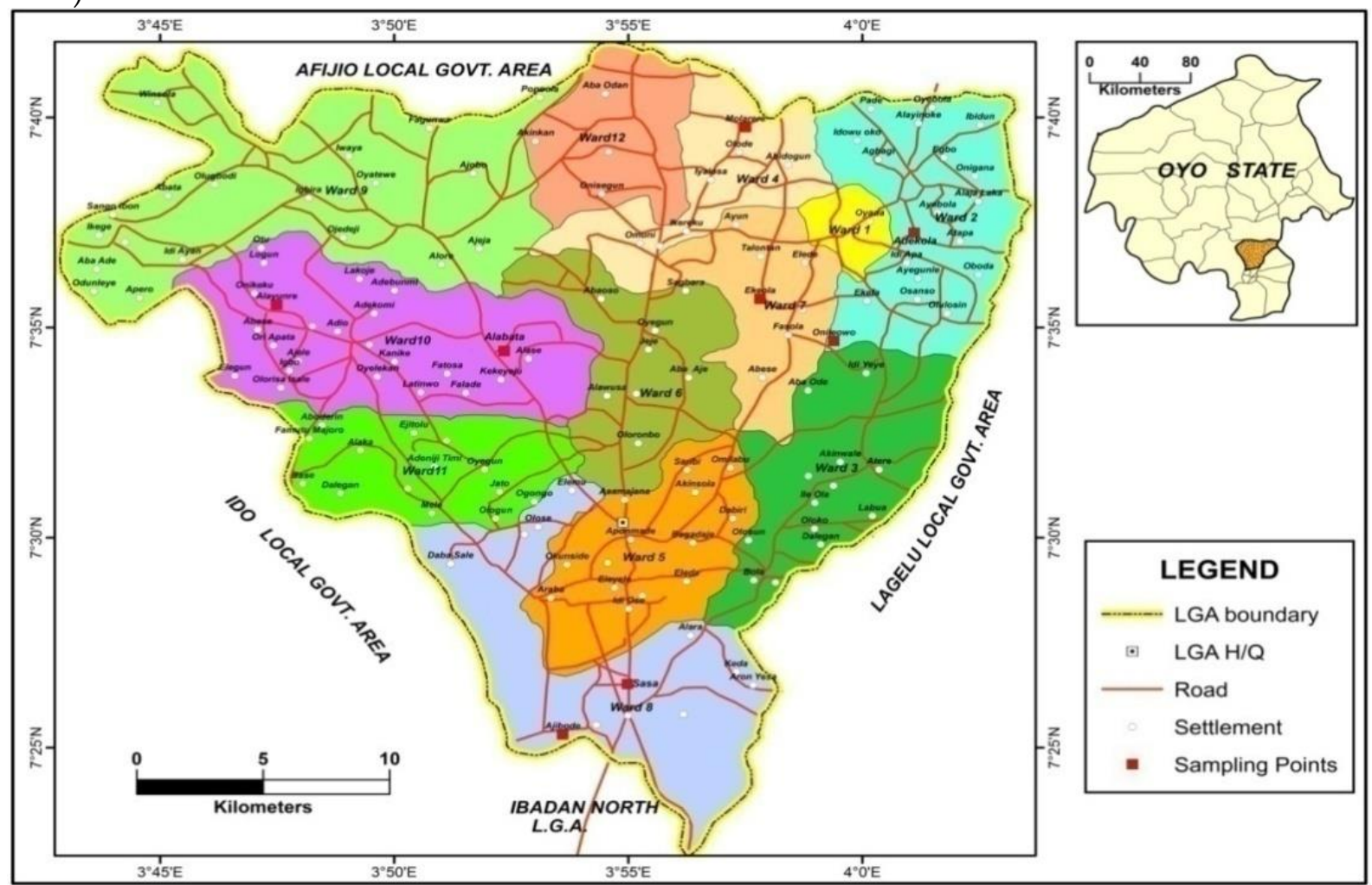

Figure 1: Map of Akinyele Local Government. (Source: GIS LAB, UNIVERSITY OF IBADAN)

Akinyele Local Government is covered with basement complex rocks, which are mainly metamorphic rocks with few intrusions of granites. The soils of the region were formed under moist semi deciduous cover and belong to the major soil group called ferruginous soil (Tokede et al., 2020).

The local government falls within the tropical wet and dry climate (Koppen climate classification $\mathrm{Aw}$ ) with a lengthy wet season and relatively constant temperatures throughout the course of the year. The wet season runs from March through October, there is usually a drop in precipitation in August. Akinyele local government falls within the rainforest region. The composition is basically the large tall crowned trees with thick undergrowth. Generally the vegetation in the area is broadly dominated by palm trees and the area may be referred to as dry forest belt

\section{METHODOLOGY}

Data on the population of registered farmers in the areas was collected from the Federal Ministry of Agricultural, Growth Enhancement Support Scheme(GESS)Akinyele chapter for the selected wards. 
TABLE 1: Selected Ward and Populations of Farmers

\begin{tabular}{ll}
\hline SELECTEDWARD & POPULATIONOFFARMERS \\
\hline Labode & 2600 \\
Alabata & 2300 \\
Ojoo & 1200 \\
\hline Source: Federal Ministry of Agricultural, Growth Enhancement Support Scheme(GESS)Akinyele chapter 2020.
\end{tabular}

Multi stage sampling was used in this research. In the first stage, three wards were purposively sampled from Akinyele local government in a manner that will ensure geographical spread. In the second stage, two communities were randomly sampled from each ward, this is because the communities are numerous and they are all crop farming communities. Finally, farmers were sampled randomly since almost everyone in these communities is farmer. The random sampling was carried out using Probability Proportional to the Sizes (PPS) of the population according to Neuman (2006). The determination of the sample size for the farmers was worked out as $10 \%$ using "Representative Sample Size" distribution suggested by Neuman (2006).

The distribution of sampled farmers according to selected wards in Akinyele L.G.A is presented in Table 2:

TABLE 2: Selected Ward and Sampled Farmers

SELECTEDWARD SAMPLED FARMERS

Labode 260

Alabata 230

Ojoo 120

Source: Fieldwork, 2020

This study employed the use of primary data. The primary data was obtained through the administration of scaled structured questionnaire to sampled farmers in the study areas. The structured questionnaire included questions on socio-economic parameters, adaptive strategies employed by farmers and their determinants.

\section{RESULTS AND DISCUSSION}

From the data presented in Table 4, majority $(70 \%)$ of the farmers are male. This implies that male dominates farming in the study area. This is in agreement with the findings of Ejembi \& Ejembi (2006) that the dominant gender in the agricultural sector in Nigeria is the male. Similarly, most of the sampled farmers fall within the age range of 31-60 years. The implication of this is that the farmers are matured enough to know the importance of employing adaptive strategies to combat the effects of climate change. Some previous studies have indicated that experienced farmers have a higher probability of using adaptive strategies to climate change as they are exposed to past and present climatic conditions over the longer perspective of their life span (Maddision, 2006;Ishaya \& Abaje 2008;Deressa \& Hassan 2009; Maddison, 2006;). 
TABLE 3: Socioeconomic Characteristics of the Selected Farmers

\begin{tabular}{lll}
\hline VARIABLES & DESCRIPTION & PERCENTAGE \\
\hline SEX & MALE & 71 \\
AGE RANGE (YEARS) & FEMALE & 29 \\
& $<30$ & 12 \\
& $31-40$ & 26 \\
& $41-50$ & 30 \\
EDUCATIONAL STATUS & $51-60$ & 22 \\
& 61-70 & 5.0 \\
& ABOVE 70 & 5.0 \\
& NO FORMAL & 26.0 \\
MARITAL STATUS & PRIMARY & 41.0 \\
& SECONDARY & 17.0 \\
SIZE OF FARMLAND & TERTIARY & 16.0 \\
& SINGLE & 20.0 \\
& MARRIED & 80.0 \\
& >1 ACRE & 28.0 \\
& 2-4 ACRE & 50.0 \\
& 5-7 ACRE & 19.0 \\
\hline
\end{tabular}

Source: Fieldwork, 2020

Furthermore Table 3 also shows that only 33\% of the farmers have post- primary education and about a quarter of the sampled farmers are not formally educated at all. This has a negative implication because their low level of education may impede access to useful climatic information and adaptive technologies. Ozor.,et al(2010) noted that poor climate change information and farmers' lack of access to weather forecast technologies are major barriers to climate change adaptation among farming households in Southern Nigeria.

Similarly, $80 \%$ of the respondents are married. Marital status is a factor, which is likely to encourage the sustainability of adoption decisions. About three-quarter of the farmers cultivate lands that are less than four acres. Most rural farmers in southwestern Nigeria are small scale holders (Adejare and Arimi, 2013).Respondents with larger farm size tend to take more proactive measures in order to reduce loss which could be greater than their counterparts with smaller farm size. This is also in agreement with Ayanwuyi.,et al (2010), observed that farm size was significantly related to farmers' adaptation strategies.About $60 \%$ of the farmers earn between the ranges of $\$ 31,000-\$ 60,000$. Only $20 \%$ of them earn higher than this. Benhin (2006) reported that lack of access to credit or saving are some of the major constraints encountered by farmers in adapting to climate change in Africa. 
TABLE 4: ADAPTIVE STRATEGIES EMPLOYED BY FARMERS

\begin{tabular}{|c|c|c|c|c|}
\hline $\begin{array}{l}\text { ADAPTIVE } \\
\text { STRATEGY }\end{array}$ & $\begin{array}{c}\text { FREQUENCY } \\
\text { YES }\end{array}$ & $\begin{array}{c}\text { PERCENTAGE } \\
\text { YES }\end{array}$ & $\begin{array}{c}\text { FREQUENCY } \\
\text { NO }\end{array}$ & $\begin{array}{c}\text { PERCENTAGE } \\
\text { NO }\end{array}$ \\
\hline $\begin{array}{l}\text { Planting of improved } \\
\text { varieties }\end{array}$ & 479 & 78.5 & 131 & 21.5 \\
\hline $\begin{array}{l}\text { Intensive } \\
\text { fertilizer/manure } \\
\text { application }\end{array}$ & 247 & 40.5 & 363 & 59.5 \\
\hline Mulching & 452 & 74.1 & 158 & 25.9 \\
\hline Contour ridging & 137 & 22.4 & 473 & 77.6 \\
\hline Shifting planting date & 212 & 34.7 & 398 & 65.3 \\
\hline $\begin{array}{l}\text { Shifting harvesting } \\
\text { date }\end{array}$ & 204 & 33.4 & 406 & 66.6 \\
\hline Move to a different site & 297 & 48.6 & 314 & 51.4 \\
\hline $\begin{array}{l}\text { Diversification into } \\
\text { other business }\end{array}$ & 283 & 46.4 & 327 & 53.6 \\
\hline $\begin{array}{l}\text { Insuring farm against } \\
\text { risk }\end{array}$ & 92 & 15 & 519 & 85 \\
\hline $\begin{array}{l}\text { Seeking early warning } \\
\text { information on climate } \\
\text { change }\end{array}$ & 215 & 35.3 & 395 & 64.7 \\
\hline $\begin{array}{l}\text { Change from crop } \\
\text { production to animal } \\
\text { rearing }\end{array}$ & 157 & 25.7 & 484 & 79.3 \\
\hline Mixed farming & 79 & 12.9 & 531 & 87.1 \\
\hline $\begin{array}{l}\text { Membership of social } \\
\text { organizations }\end{array}$ & 483 & 79.1 & 134 & 21.9 \\
\hline $\begin{array}{l}\text { Avoidance of flood } \\
\text { prone areas }\end{array}$ & 232 & 38.0 & 378 & 62.0 \\
\hline
\end{tabular}

Source: Fieldwork, 2020

Majority of the farmers $(78.5 \%)$ plant improved varieties of crops while a lesser but substantial percentage (59.5)apply fertilizer on their farms. Kawasaki and Herath (2011) observed that improved crop varieties have high capacities for coping with climate change. Most of the farmers employ mulching while contour ridging is practiced by a small percentage $(22.4 \%)$. Only a third of them practice the changing of planting and harvesting dates in the area while close to half of them are able to move to a different farm site or diversify their means of livelihood when the need arises. Some adaptive strategies like insuring farm against risk, change from crop production to animal rearing and mixed 
farming are not significantly employed in the area. More than half of the sampled farmers seek early warning information on climate change. About $36 \%$ of the sample farmers seek early warning information on climate change. Most of the farmers are members of social organizations.

Table 6: Results of Regression Analysis

\begin{tabular}{|c|c|c|c|c|c|c|c|c|c|c|}
\hline & B & S.E & Wald & Df & Sig. & $\begin{array}{l}\operatorname{Exp}(B \\
)\end{array}$ & $\begin{array}{l}95 \% \\
\text { EXP(B }\end{array}$ & C.I.for & $\begin{array}{l}\text { Relationshi } \\
\text { p }\end{array}$ & $\begin{array}{l}\text { Significan } \\
\mathbf{t} \\
\text { Difference }\end{array}$ \\
\hline $\begin{array}{l}\text { Planting of } \\
\text { improved } \\
\text { varieties }\end{array}$ & 0.841 & 0.023 & 8.247 & 1 & 0.001 & 1.081 & 1.031 & 2.974 & Positive & Significant \\
\hline $\begin{array}{l}\text { Intensive } \\
\text { fertilizer/manur } \\
\text { e application }\end{array}$ & 0.005 & 0.231 & 0.546 & 1 & 0.421 & 1.004 & 0.853 & 1.876 & Positive & Significant \\
\hline Mulching & 0.910 & 0.541 & 5.356 & 1 & 0.010 & 1.974 & 0.543 & 9.645 & Positive & Significant \\
\hline Contour ridging & 1.950 & 0.345 & 5.765 & 1 & 0.970 & 0.615 & 0.423 & 1.753 & Positive & $\begin{array}{l}\text { Not } \\
\text { Significant }\end{array}$ \\
\hline $\begin{array}{l}\text { Shifting } \\
\text { planting date }\end{array}$ & -1.750 & 0.342 & 6.874 & 1 & 0.011 & 0.543 & 0.870 & 6.534 & Negative & Significant \\
\hline $\begin{array}{l}\text { Shifting } \\
\text { harvesting date }\end{array}$ & -0.617 & 0.000 & 2.453 & 1 & 0.021 & 0.654 & 2.097 & 6.439 & Negative & Significant \\
\hline $\begin{array}{l}\text { Move to a } \\
\text { different site }\end{array}$ & -0.657 & 0.126 & 5.643 & 1 & 0.044 & 7.026 & 1.086 & 4.231 & Negative & Significant \\
\hline $\begin{array}{l}\text { Diversification } \\
\text { into other } \\
\text { business }\end{array}$ & -1.760 & 0.453 & 9.675 & 1 & 0.000 & 6.453 & 3.097 & 6.864 & Negative & Significant \\
\hline $\begin{array}{l}\text { Insuring farm } \\
\text { against risk }\end{array}$ & 1.860 & 0.654 & 2.655 & 1 & 0.002 & 1.056 & 0.534 & 1.506 & Positive & Significant \\
\hline $\begin{array}{l}\text { Seeking early } \\
\text { warning } \\
\text { information on } \\
\text { climate change }\end{array}$ & 1.970 & 0.543 & 0.000 & 1 & 0.032 & 1.067 & 0.765 & 0.999 & Positive & Significant \\
\hline $\begin{array}{l}\text { Change from } \\
\text { crop production } \\
\text { to animal } \\
\text { rearing }\end{array}$ & -1.766 & 0.654 & 0.564 & 1 & 0.567 & 1.276 & 0.763 & 0.834 & Negative & $\begin{array}{l}\text { Not } \\
\text { Significant }\end{array}$ \\
\hline Mixed farming & -1.875 & 0.564 & 0.345 & 1 & 0.087 & 1.754 & 0.865 & 1.965 & Negative & $\begin{array}{l}\text { Not } \\
\text { Significant }\end{array}$ \\
\hline $\begin{array}{l}\text { Membership of } \\
\text { social } \\
\text { organisations }\end{array}$ & -1.007 & 0.765 & 0.453 & 1 & 0.231 & 1.982 & 0.003 & 0.567 & Negative & $\begin{array}{l}\text { Not } \\
\text { Significant }\end{array}$ \\
\hline $\begin{array}{l}\text { Avoidance of } \\
\text { flood prone } \\
\text { areas }\end{array}$ & 1.654 & 0.342 & 0.231 & 1 & 0.004 & 7.430 & 0.006 & 0.423 & Positive & Significant \\
\hline Constant & $\begin{array}{l}- \\
2.26 \\
0\end{array}$ & .303 & $\begin{array}{l}0.34 \\
2\end{array}$ & 1 & .000 & .104 & & & & \\
\hline
\end{tabular}

The result in Table 6 reveals Planting of improved varieties $(0.841,0.001)$ intensive fertilizer/manure application $(0.005,0.421)$ mulching $(0.910,0.010)$ insuring farm against risk(1.860,0.002), seeking early warning information on climate change $(1.970,0.032)$ and avoidance of flood prone areas $(1.654,0.004)$ have positive and significant relationship in determining farmer's adaptation strategies while contour ridging $(1.950,0.970)$ has positive but not significant relationship in determining farmer's adaptation strategies. Shifting planting date $(-1.750,0.011)$, Diversification into other business $(-1.760,0.000)$,Shifting harvesting date $(-0.617,0.021)$, Move to a different site $(-0.657,0.044)$ have negative but significant relationship in determining farmer's adaptation strategies while Change from crop production to animal rearing $(-1.766,0.567)$, Mixed farming $(-1.875,0.087)$, Membership 
of social organizations $(-1.007,0.231)$ has negative and insignificant relationship in determining farmer's adaptation strategies.

\section{CONCLUSION}

It can be concluded from the research that planting of improved varieties, mulching and membership of social organizations are adaptive strategies that are strongly employed by farmers in Akinyele L.G.A. It is recommended that farmers in the area should be enlightened about the importance of seeking early warning information on climate change by concerned authorities. This will enhance their ability to adjust planting and harvesting dates accordingly. The enlighten campaign should also beam its light on the merits of diversification.

\section{REFERENCES}

Abel.A.Adebayo. (2010). Climate:Rescource and resistance to agriculture. Eight Inaugual Lecture Federal University of Technology Yola. Yola: Lectures and Proceedings of Prizes Commitee Federal University of Technology Yola.

Action Aid. (2008). The time is now:Lesson from farmers to adapting to climate change. Adaptation to climate change (pp. 17-19). Havana, Cuba: UNDP.

Adejare, G.T \& Arimi,K. (2013). Determinants of labour use for selected tree crops in Oyo and Ondo States,Nigeria. New York Science Journal ,6 (8) 76.

Adger,W.N.,Huq.S.,Brown,K., Conway,D and Hulme,M (2003). Adaptation to climate change in the developed world. Progress in Development Studies 3 , 179-195.

Anyawuyi, E,.Kuponiyi,F.A \& Ogunlade,O.J . (2010). Farmer's perception of impact of climate changes on food crop production in Ogbomoso Agricultural Zone of Oyo state,Nigeria. Global Journal of Human and Social Sciences $10,33$.

Arimi, K. (2014). Determinants of climate change adaptation strategies used among fish farmers in Epe local goverment areas of Lagos state,Nigeria. Journal of the Science and Food and Agriculture, 94 (7),1470-1476.

Aye, A. (2013). Efficiency and policy analysis in agriculture:Methods and applications. Lambert Academic Publishing.

Benhin, J.K.A. (2006). Climate change and South African Agriculture:Impacts and adaptation optios. CEEPA Discussion Paper No.21. Pretoria:: University of Pretoria,Centre for Enviromental Economics and Policy in Africa.

Bradshaw,B.,Dolan,H.,\& Smit,B (2004). Farm-level adaptationto climate variability and change. Crop diversification in the Canadian prairies , 119-141.

Deressa, T. T \&.R.M Hassan (2009). Economic Impact of Climate Change on Crop production in Ethiopia.Evidence from Cross section Measures. Journal of African Economies , 529-554.

Ejembi EP \& Ejembi SA (2006). Farmer's assessment of the training and visit extension system in central Nigeria:Evidence from Barkin Ladi Plateau State. Journal of Social Sciences , 207-212.

Hassan, R \& Nhemachena (2008). Determinants of African farmers' strategies for adapting to climate change:Multinomial choice analysis. African Journal of Agricultural and Rescource Economics , 83-104.

Intergovermntal Panel on Climate Change. (2007). Impact,adaptation and vulnerability.Contribution of Working Group II to the Third Assesment Report of the Intergovermental Panel on Climate Change. Cambridge,United Kingdom: Cambridge University Press.

Ishaya, S. \& Abaje ,I.B.. (2008).Indigenous people's perception of climate change and adaptation strategies in Jema's local government area of Kaduna State,Nigeria. Journal of Geography and Regional Planning .1 (18),pp. , 138-143. 
Kawasaki, J. \& Herath,S . (2011). Impact assesment of climate change on rice production in Khonkaen Province,Thailand. ISSAAS Journal 17 (2) , 14-28.

Kurkulasuriya,P \&.Mendelsohn,R (2008). A Ricardian analysis of the impact of climate change on African cropland. African Journal of Agricultural and Rescource Economics 2 , $1-23$.

Maddision. (2006). The perception and adaptation to climate change in Africa. Pretoria,South Africa: Centre for Enviromental Economics and Policy in Afica.

Neuman, W. (2006). Social Research Methods:Qualitative and Quantitative Approaches. Boston.

Nhemachena, C. and Hassan R. (2007). Micro-level analysis of farmer's adaptation to climate change in Southern Africa. IFPRI Disscusion Paper No 00714 (pp. 83-104). Washington DC: International Food Policy Research Institute.

Obatolu, C. R., Fashina,A.B \& Olaiya A.O. (2003). Effects of climate change on cocoa production in Nigeria. African Crop Science Conference Proceedings (pp. 957-966). Lagos,Nigeria: African Crop Science Society Volume 5.

Oji-Okoro. (2011). Analysis of the contribution of agricultural sector in the Nigerian economic development. World Review of Bussiness Research , 191-200.

Oyekale, A.S., Bolaji.M.B.\&Olowa,O.W. (2009). The effects of climate change on cocoa production in Nigeria and vulnerability assessment in Nigeria. Agricultural journal , 4 (22) $77-85$.

Oyekake, A.S \&Oladele,O.I. (2012). Determinants of climate change adaptation among cocoa farmers in southwest Nigeria. ARPN Journal of Science and Technology , 2,Special issue,154-168.

Ozor, N; Madukwe,M.C;Enete,A.A ;Amaechina,E.C;Onokola,P;Eboh,E,C; et al .,(2010). Barriers to climate change adaptation among farming households of Southern Nigeria. Journal of Agricultural Extension 14 , 114-124.

Seo,N., \& Mendelsohn,R (2008). Animal husbandry in Africa:Climate Change impacts and adaptations. African Journal of Agricultural and rescource economics , 65-82.

Smit, B.\& Skinner ,M.W. (2002). Adaptation options in agriculture to climate change:A typology. Mitigation and Adaptation Strategies for Global Change 7 , 85-114.

Tokede, Am., Banjo, Aa; Ahmad, Ao; Fatoki,Oa; \& Akanni. (2020). Famer's Knowledge and attitude towards the adoption of agroforestry practices in Akinyele local goverment area. Nigeria Journal of Applied Sciences and Enviromental Management Vol.24 , 17751780 . 